\title{
RADAR SOUNDINGS ON THE PENNY ICE CAP, BAFFIN ISLAND
}

\author{
By J. R. Weber and Pierre Andrieux \\ (Observatories Branch, Department of Energy, Mines and Resources, Ottawa, Ontario, \\ Canada)
}

\begin{abstract}
Anstract. The first successful radar echo soundings through glacier ice in Canada were carried out by the Dominion Observatory in I965 on an outlet glacier of the Penny Ice Cap in Baffin Island. An unmodified 440 MHz SCR-7 18 radar altimeter was used, of the type that is readily and inexpensively available on the surplus market. The radar soundings were generally in agreement, within the range of the reading accuracy of the oscilloscope $( \pm 15 \mathrm{~m})$, with depths obtained seismically, gravimetrically, and by the electrical resistivity method. The minimum and maximum recorded depths were $45 \mathrm{~m}$ and $550 \mathrm{~m}$, respectively. The pip positions on the standard oscilloscope were recorded visually. This recording method was not satisfactory, but for future use the instrument could easily be modified to incorporate a larger oscilloscope with continuous photographic recording. Use of the relatively high carrier frequency of $44^{\circ} \mathrm{MHz}$ (compared with the more customary frequency of about $35 \mathrm{MHz}$ ) allows the use of smaller antennas and results in better resolution of the bedrock surface.
\end{abstract}

RÉsumÉ. Sondages radar sur le Penny Ice Cap, Baffin Island. Les premiers sondages par radar réussis sur les glaciers au Canada ont été exécutés par le Dominion Observatory en 1965 sur la calotte Penny Ice Capsur Baffin Island. Un radioaltimètre $\mathrm{SCR}-718$ non modifié à $440 \mathrm{MHz}$, qui peut être obtenu façilement et bon marché dans les magasins de surplus, a été employé. En tenant compte de l'incertitude de lecture de l'oscilloscope ( $\pm \mathbf{I} 5 \mathrm{~m}$ ), les résultats concordent en général avec ceux obtenus par les méthodes séismiques, gravimétriques et électriques. La profondeur minimum et maximum est de $45 \mathrm{~m}$ et $550 \mathrm{~m}$ respectivement. La cote visuelle de l'oscilloscope est insuffisante, mais il est facile d'utiliser un écran plus grand et un enregistreur photographique continu. La fréquence fondamentale relativement haute de $440 \mathrm{MHz}$ (comparé avec la fréquence plus habituelle d'environ $35 \mathrm{MHz}$ ) permet d'utiliser des antennes plus petites et d'obtenir ainsi une meilleure résolution de la surface du socle rocheux.

Zusammenfassung. Radar Echolotungen auf Penny Ice Cap, Baffin Island. Die erste erfolgreiche Echolotung durch Gletschereis in Kanada wurde vom Dominion Observatory im Jahre 1965 auf einem Gletscher des Penny Ice Cap auf Baffin Island durchgeführt. Ein nichtmodifiziertes $440 \mathrm{MHz}$ Modell SCR-71 8 Flugzeug Radar Echolot, das verhältnismässig günstig aus Restbeständen erhältlich ist, wurde verwendet. Innerhalb der Ablesegenauigkeit des Oszilloskopes ( $\pm 15 \mathrm{~m}$ ) stimmten die Radarlotungen im allgemeinen mit den Tiefen überein, wie sie seismisch, gravimetrisch und mit der geoelektrischen Widerstandsmethode gefunden wurden. Die minimale Lotungstiefe war $45 \mathrm{~m}$, die maximale $550 \mathrm{~m}$. Die Ablesestellen auf dem normalen Oszilloskop wurden visuell notiert. Diese Aufschreibemethode war nicht befriedigend, aber für künftigen Gebrauch könnte durch Einbau eines grösseren Oszilloskops mit kontinuierlicher photographischer Registrierung modifiziert werden. Die relative hohe Trägerfrequenz von $440 \mathrm{MHz}$ (verglichen mit der gebräuchlicheren Frequenz von rund $35 \mathrm{MHz}$ ) erlaubt die Anwendung kleinerer Antennen und gibt eine bessere Auf lösung des Gletscherbodens.

\section{INTRODUCTION}

In the spring of 1962 the Dominion Observatory initiated a long range geophysical and glaciological programme on the Penny Ice Cap in Baffin Island which requires observations to be repeated periodically every three to four years $(I c e, \mathrm{I} 963[\mathrm{a}],[\mathrm{b}], \mathrm{I} 966)$. The objectives are to measure elevation changes using gravity meters and to investigate the ice flow by measuring the movement of 14 aluminum poles permanently drilled into the ice across the crest of the ice cap. Figure I shows the location of the 14 movement poles (labelled S-I to S-7, and $\mathrm{N}-\mathrm{I}$ to $\mathrm{N}-7$ ) on the Penny Ice Cap as well as the positions of four markers on solid rock, "East Base", "West Base", "Signal Hill" and "Toboggan Peak", relative to which the pole movements are measured. "Gravity Base" is a rock outcrop relative to which all gravity intervals to the movement poles are measured.

During April and May 1965 the first periodic re-survey was carried out. As part of the program the ice thickness across the ice cap and along a large outlet glacier was measured using radar, seismic, gravity and electrical resistivity techniques. The large dots in Figure I labelled T-o to T-5 mark the position of the line along which the soundings were made. 


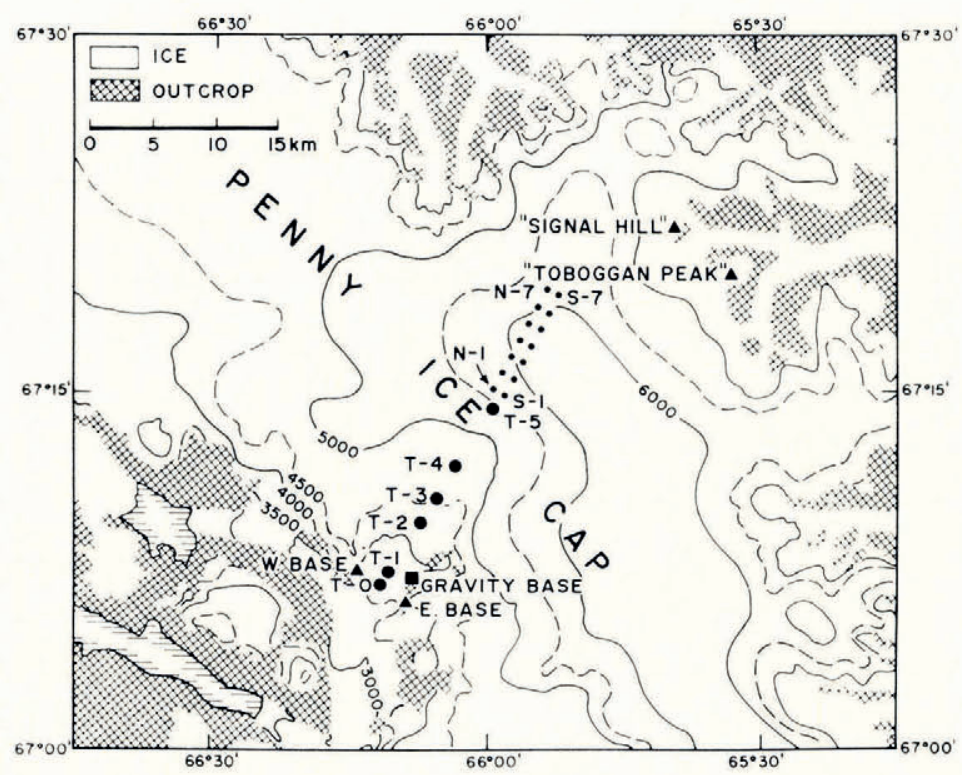

Fig. I. Sketch map of the central part of the Penny Ice Cap. The small dots labelled $\mathcal{N}-1$ to $\mathcal{N}-7$ and $S-I$ to $S-7$ represent $1+$ aluminum poles that were permanently drilled into the ice in 1962 and were surveyed relative to rock markers named "Toboggan Peak", "Signal Hill", "West Base" and "East Base". The large dots labelled T-o to T-5 are tellurometer stations along the profile where depth soundings were made. All gravity measurements were measured relative to a rock station labelled "Gravity Base".

\section{INSTRUMENTATION AND SOUNDING TECHNIQUE}

The radar sounding equipment consisted of an unmodified SCR-7 8 radar altimeter on loan from the Royal Canadian Air Force. The peak power output of this $440 \mathrm{MHz}$ pulsed type altimeter is $7 \mathrm{~W}$ and the reading accuracy on the standard oscilloscope is $\pm 15 \mathrm{~m}$ (as measured in ice). Figure 2 shows the sounding equipment mounted on a Nansen sledge that was pulled by a motor toboggan. Of the two boxes mounted on top of each other the lower contained two nickel-cadmium batteries and a i Io $\mathrm{V} 400 \mathrm{~Hz}$ dynamotor and the upper housed the SCR-71 8 radar set with the oscilloscope. On top, mounted on either side of a $6 \mathrm{~m}$ pole, were the transmitting and receiving dipole antennas backed by $75 \mathrm{~cm} \times 90 \mathrm{~cm}$ aluminum reflectors. During sounding operations the batteries were continuously charged by a $28 \mathrm{~V}$ I $500 \mathrm{~W}$ gasoline driven generator. To obtain a depth measurement the vehicle had to be moving because the oscilloscope always showed a multitude of pips apparently caused by scattered reflections, and recognition of the recurring dominant bottom reflection from the multitude of seemingly random reflections depended on the skill of the observer. A pip position observed when the vehicle was standing still was therefore not necessarily a reflection from the bottom.

Seismic reflections were obtained using a modified 12-channel Electro-Tech recording interval timer and an L-shaped array of twelve $30 \mathrm{~Hz}$ geophones. The compressional wave velocities in the glacier ice were known from seismic refraction profiles shot on the ice cap and on the center part of the outlet glacier in 1962 .

The gravity measurements were made with two LaCoste and Romberg geodetic gravity meters, numbers G-74 and G-75, which were transported on a Nansen sledge pulled by a motor toboggan. Readings were obtained at each tellurometer station and at each wooden peg described in the next section.

The electrical resistivity measurements, which are described elsewhere (Andrieux, unpublished), were made using an array of the asymmetrical Schlumberger type. 


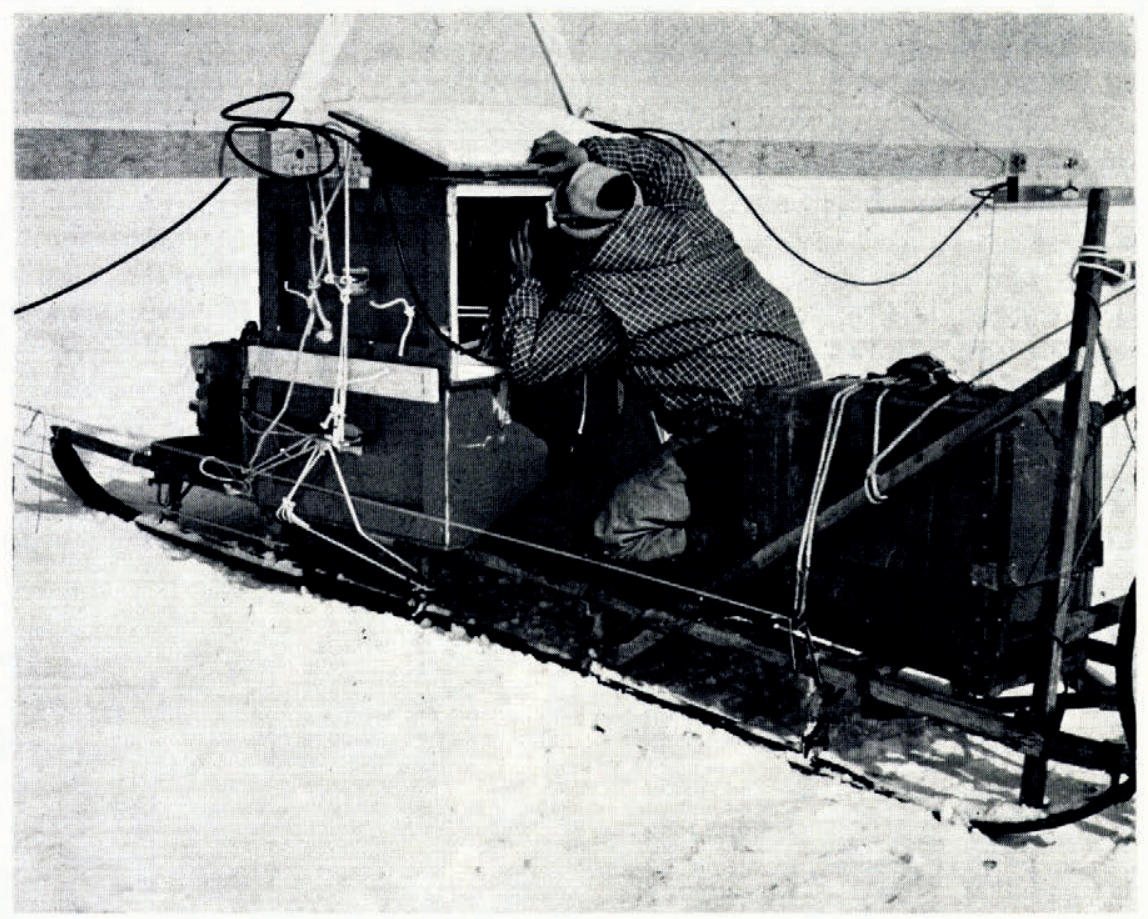

Fig. 2. Radar sounding equipment mounted on a Nansen sledge with Pierre Andrieux observing the oscilloscope. Two boxes are mounted on top of each other; the upper houses transceiver and oscilloscope, the lower contains nickel-cadmium batteries charged by a $28 V_{I} 500 \mathrm{~W}$ generator fastened to the front of the sledge. Transmitting and receiving antennas with reflectors are connected to either end of a $6 \mathrm{~m}$ pole. The sledge is pulled by a motor toboggan.

\section{SURVEY METHOD}

The profile along which radar, seismic, gravity and electrical resistivity measurements were made is $18 \mathrm{~km}$ long. It starts at the movement pole S-I at the edge of the ice cap and follows the center line of a large outlet glacier along the tellurometer stations $\mathrm{T}-5$ to $\mathrm{T}$-o. The distances between flags $\mathrm{T}-\mathrm{o}$ to $\mathrm{T}-5$ were measured by tellurometer and elevations between flagged stations were determined by measuring simultaneous reciprocal angles with two theodolites. In addition, the positions and elevations of stations T-o, T-4 and S-I were determined by a combination of triangulation and tellurometer trilateration from the rock stations "East Base" and "West Base" (Fig. I). Along the profile line wooden pegs with clearly visible numbers were stuck in the snow every $160 \mathrm{~m}$, and distances were taped to the nearest tellurometer station. Distances between pegs were measured with a bicycle-wheel odometer mounted behind the sledge. Elevations of the pegged stations were repeatedly determined barometrically using the known elevations of tellurometer stations as control. On each subsequent up or down run of the radar equipment the odometer reading was recorded at each peg.

\section{SOUNDING RESULTS}

The radar altimeter was calibrated to measure distances in feet through air; for sounding through ice the readings had to be multiplied by the conversion factor $I / \dot{\epsilon}^{\prime \frac{1}{2}}$, where $\dot{\epsilon}^{\prime}$ is the apparent dielectric constant for ice. For a given frequency the value for $\dot{\epsilon}^{\prime}$ increases slightly 
with increasing temperature and increasing density, and therefore with increasing ice thickness (Ragle and others, 1964). The soundings ranged in depth between $15^{\circ} \mathrm{m}$ and $55^{\circ} \mathrm{m}$, and based on an observed mean annual temperature of $-13^{\circ} \mathrm{C}$ at $183^{8} \mathrm{~m}$ elevation it is estimated that the ice temperature near the glacier surface along the profile from $\mathrm{S}$ - I to T-o ranges from $-12.5^{\circ} \mathrm{C}$ to $-8^{\circ} \mathrm{C}$. Waite and Schmidt ( 1962 ) used a value for $\dot{\epsilon}^{\prime}=3.2$ for similar ice conditions in Greenland and Antarctica. Waite's figure of 3.2 was used to convert our radar readings to ice thicknesses. More recent work (Evans, 1965; Robin and Evans, unpublished) suggest that the apparent dielectric constant for the Penny Ice Cap might be nearer 3.17 or 3.18 . The difference in computed depth based on dielectric constants of 3.17 and 3.20 is, however, smaller than the reading accuracy of the oscilloscope $\left( \pm \mathrm{I}_{5} \mathrm{~m}\right.$ ).

The results of the radar, seismic, gravity, and electrical resistivity soundings are shown in Figure 3. The radar soundings along the profile were repeated a number of times, and the reflected signal was always lost above $\mathrm{S}-\mathrm{I}$, above $\mathrm{T}-4$, above $\mathrm{T}-\mathrm{I}$, and below $\mathrm{T}-\mathrm{o}$, that is to say wherever the ice thickness, according to the gravity, seismic, or electrical method, exceeded $500 \mathrm{~m}$ to $55^{\circ} \mathrm{m}$. This indicates that the sounding limit of the instrument lies in the $500 \mathrm{~m}$ to $55^{\circ} \mathrm{m}$ range.

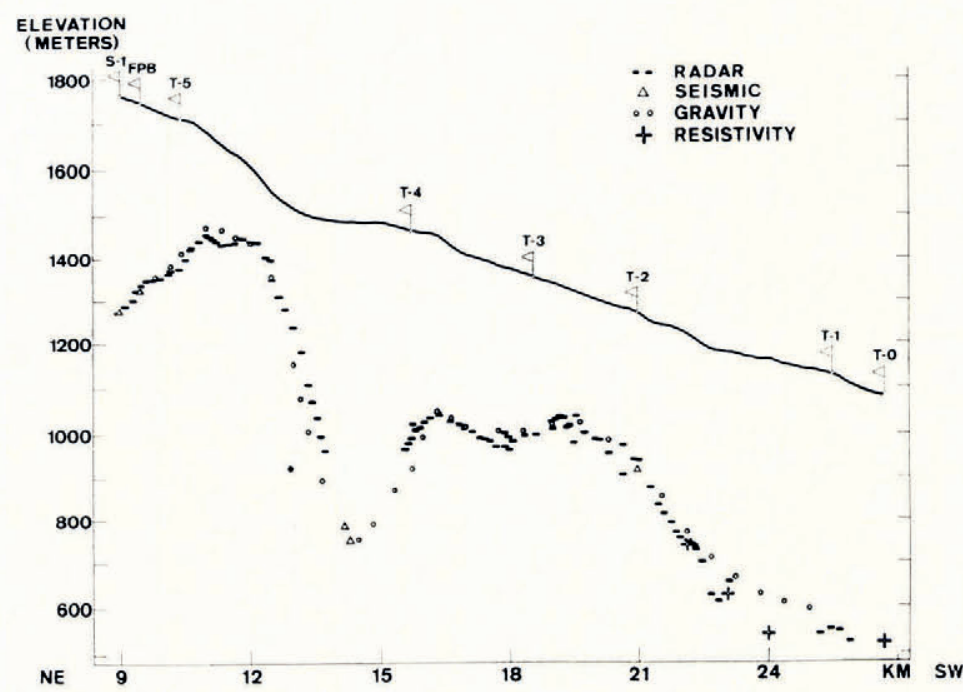

Fig. 3. Glacier surface and bedrock profile between stations $S-I$ and $T$-o. Soundings obtained from radar, seismic, gravity and electrical resistivity measurements are shown. The deepest observed radar sounding was $500 \mathrm{~m}$.

There is generally good agreement between radar soundings on the one hand, and the seismic, resistivity and gravity soundings on the other. The seismic and resistivity soundings lie everywhere within the reading accuracy of the radar soundings $( \pm 15 \mathrm{~m}$ ); gravity and radar soundings differ by less than $10 \%$ except in an area between $\mathrm{T}-4$ and $\mathrm{T}-5$ where the gravity soundings differ as much as $30 \%$ from the radar soundings. Gravity is used to interpolate depth between points of known seismic thickness. These interpolated values are calculated from the difference between the observed Bouguer anomaly at the glacier surface and the Bouguer anomaly at the bedrock surface. The former is calculated from the observed gravity, the geographical latitude, and the measured surface elevation; the latter is known only at points where the ice thickness was determined seismically, and the regional Bouguer anomaly is interpolated as the smoothest fitting curve between the seismic points (Weber, I $96 \mathbf{I}$ ). An erroneous depth is therefore most likely to be caused by a wrong interpolation of the bedrock anomaly (caused by sudden density changes in the bedrock lithology), or by terrain 
effects that have been neglected. Where gravity and radar depths disagree it is therefore more likely that the gravity depth is in error. By rotating the antennas in such a way that the antenna reflectors were parallel with the underlying bedrock surface, soundings were attempted near the edge of the glacier below station T-o. However, the noise level in the oscilloscope was so high that it masked any recognizable reflections. Similarly, no englacial reflections were identified with certainty. It is possible that by using continuous photographic recording both echoes from the side of the glacier and from intermediate layers within the ice could have been recognized.

\section{Discussion}

Our work under typical Arctic conditions in a mountainous region in temperatures as low as $-30^{\circ} \mathrm{C}$ proved that the instrument is rugged and reliable. The relatively high frequency of $440 \mathrm{MHz}$, compared with the more customary 30 to $35 \mathrm{MHz}$, allows the use of greater band width and smaller antennas resulting in a narrower beam width and in better resolution of the bedrock surface and englacial layers. However, it lacks the high penetration power of its $35 \mathrm{MHz}$ rivals with which reflections through $3000 \mathrm{~m}$ of ice have been obtained (Waite, 1966). The minimum sounding depth of an unmodified SCR-71 8 is $45 \mathrm{~m}$ owing to the radar pulse length. Another consideration is cost: The SCR-7I 8 radar altimeter is still used in many aircraft today and is readily available on the surplus market; a recent enquiry from surplus outlets showed that the price for a complete unit ranges from 200 to 400 dollars in the U.S.A., and from 300 to 400 dollars in Canada.

The drawback of the instrument when used without modification and when pulled slowly over a glacier is that it is difficult for the observer to recognize the dominant bottom reflection; it is even more difficult to recognize small englacial reflections. Moreover the recognition of the bottom pip depends on the judgement of the observer at the time, and no permanent record is obtained. However, the small standard oscilloscope could be replaced by a larger one adapted for continuous photographic recording, and with only minor modifications the power output of the unit could be at least tripled. These modifications would make a sounder ideal for use on medium sized glaciers by expeditions with limited financial resources, an instrument which, within its depth range, is comparable in performance with specially designed radio sounders costing many times as much.

\section{Acknowledgements}

We wish to thank Mr Amory Waite, formerly of the U.S. Army Signal Research and Development Laboratory, Fort Monmouth, New Jersey for his technical advice on the use of the SCR-7 8 radar altimeter; and K. C. Arnold and Axel Geiger, both of the Department of Energy, Mines and Resources, Ottawa, who were responsible for the triangulation and the tellurometer survey.

\section{MS. received 4 November 1968 and in revised form 4 August 1969}

\section{REFERENCES}

Andrieux, P. Unpublished. Application des méthodes électriques à l'étude de la glace et des glaciers. [Thesis Diplôme d'ingénieur géophysicien de l'Institut de Physique du Globe de Strasbourg, 1967.]

Evans, S. 1965. Dielectric properties of ice and snow-a review. Fournal of Glaciology, Vol. 5, No. 42, p. 773-92. Ice. $1963[\mathrm{a}]$. Ice: News Bulletin of the Glaciological Society, No. I I, p. 8.

Ice. 1963 [b]. Ice: News Bulletin of the Glaciological Society, No. 12, p. 8.

Ice. 1966. Ice: News Bulletin of the Glaciological Society, No. 20, p. 5.

Ragle, R. H., and others. 1964 . Ice core studies of Ward Hunt Ice Shelf, r960, by R. H. Ragle, R. G. Blair and L. E. Persson. Journal of Glaciology, Vol. 5, No. 37, p. 39-59. 
Robin, G. de Q., and Evans, S. Unpublished. Electromagnetic properties of ice and snow. [Paper presented at the Réunion internationale sur le sondage par radio-écho de la glace et des glaciers, Strasbourg, September 1967.]

Waite, A. H., jr. 1966. International experiments in glacier sounding, 1963 and 1964. Canadian Journal of Earth Sciences, Vol. 3, No. 6, p. 887-92.

Waite, A. H., jr., and Schmidt, S. J. 1962. Gross errors in height indication from pulsed radar altimeters operating over thick ice and snow. Proceedings of the Institute of Radio Engineers, Vol. 50, No. 6, p. I515-20.

Weber, J. R. 1961. Comparison of gravitational and seismic depth determinations on the Gilman Glacier and adjoining ice-cap in northern Ellesmere Island. (In Raasch, G. O., ed. Geology of the Arctic: proceedings of the first international symposium on Arctic geology held in Calgary, Alberta, January $1 I_{-13}, 1960$ under the auspices of the Alberta Society of Petroleum Geologists. Toronto, University of Toronto Press, Vol. 2, p. $781-90$. 